Egyptian Journal of Aquatic Biology \& Fisheries

Zoology Department, Faculty of Science,

Ain Shams University, Cairo, Egypt.

ISSN $1110-6131$

Vol. 25(4): 899 - 907 (2021)

www.ejabf.journals.ekb.eg

Effect of different cooking techniques on quality characteristics of some fish species

\author{
Mohamed Abou-Taleb, Sayed M. Ibrahim, Shaban El-Sherif, Abdelrahman S. Talab* \\ Fish Processing and Technology Laboratory, \\ National Institute of Oceanography and Fisheries, Cairo, Egypt. \\ "Corresponding Author:Abdelrahman_saidh@yahoo.com
}

\begin{abstract}
ARTICLE INFO
Article History:

Received: July 28, 2021

Accepted: Aug. 19, 2021

Online: Aug. 30, 2021

Keywords:

fish fillets,

quality characteristics, cooking methods,

Qarun Lake.

This work was performed to study the effect of cooking techniques on the quality characteristics of some fishes. Four samples; Mugil cephalus, Liza ramada, Tilapia zilli, and Solea vulgaris were obtained from Qarun Lake as the most important and abundant fish. All samples were manually filleted, brined, and then cooked using frying, microwave, and halogen techniques. Sensory, physicochemical, and microbial properties of raw and cooked fillets were determined. The results indicated that fried fish products were the best in texture and acceptability compared with microwave and halogen-cooked products. Cooking methods led to changes markedly in the values of moisture, $\mathrm{pH}$ value, total volatile basic nitrogen (TVBN), trimethylamine (TMA), thiobarbituric acid value (TBA) and total plate count (TPC), while increased levels of protein, fat, and ash contents. In conclusion, the quality properties of different cooked fishery products are dependent mainly on fish species and the cooking method used.
\end{abstract}

\title{
INTRODUCTION \\ INTRODUCTION
}

Fish is known to be a source of protein, rich in essential amino and it contains micro- and macro elements and fat-soluble vitamins (Larsen et al., 2007). With regard to muscles foods, consumers look for high quality and convenient meat and fish products containing natural flavor, fresh appearance and nutrients. Additionally, safe and natural products without additives such as preservatives and humectants are being demanded (Hugas et al., 2002). Chemical and physical reactions are take place during cooking process (e.g. boiling, baking, roasting, frying and grilling) which both improve the food nutritional quality and enhances digestibility and bio-availability of nutrient in the digestive tract (Bognar, 1998 and Kocatepe et al., 2011). Also, several authors (Oğuzhan \& Angis, 2013 and Talab, 2014) have been reported that cooking methods had the effect on the major constituents and quality criteria of fish products however; others mentioned that cooking methods had little influence (Koubaa et al., 2012) or did not affect chemical composition but influenced the texture and color parameters (Bainy et al., 2015). Therefore, this work was designed to study the effect of different cooking techniques (frying, microwave and halogen) on quality characteristics of the most 
important and abundant fishes; Mugil cephalus, Liza ramad, Tilapia zilli and Solea vulgaris obtained from Qarun Lake.

\section{MATERIALS AND METHODS}

\section{Materials}

Four fish samples; grey mullet (Mugil cephalus), thin lip mullet (Liza ramad), tilapia (Tilapia zilli) and sole fish (Solea solea) were obtained from Qarun Lake. Total weight of fish samples were 250, 150, 80 and $60 \mathrm{~g}$, respectively. Fish samples were transferred using ice box to Fish Processing Technology Lab., El-Kanater El-Khairia Branch, National Institute of Oceanography and Fisheries (NIOF) within 3 hrs. Sunflower oil, table salt, wheat flour were obtained from local market.

\section{Cooking techniques}

Fish samples were washed with tap water, eviscerated and filleted and washed again. Skins off fillets of each species were randomly divided to 4 batches. The first batch was raw and remaining three batches were brined (saturated for $2 \mathrm{~min}$ at $26{ }^{\circ} \mathrm{C}$ ), washed, drained, rubbed in wheat flour, left for 3-4 min and cooked by frying, microwave and halogen techniques as follows: Deep-oil frying was done at $180{ }^{\circ} \mathrm{C}$ for $10 \mathrm{~min}$. $(5 \mathrm{~min}$ of each side) using a domestic pan (2 liter capacity), then drained in basket to remove excess oil. Microwaving was performed for $6 \mathrm{~min}$ in a Microwave oven (Zipel DG 68-00216B01, Samsung, Gwangin, Korea) and Halogen cooking was performed using electric Halogen oven (Lentel, model KYR-912A, $1300 \mathrm{C}$ watt) at $180^{\circ} \mathrm{C}$ for $20 \mathrm{~min}(10 \mathrm{~min}$ of each side).

\section{Analytical methods}

Sensory characteristics (color, taste, odor, texture and overall acceptability) of cooked fish samples were evaluated by ten panelists and hedonic rating scale, where 9 point means "like extremely" and 1.0 means "disliked extremely" (Karamer \& Twigg, 1970). The data "judge's results" were analyzed statistical using Duncan test as outlined by Steel \& Torri (1980). Proximate composition; moisture, protein $(\mathrm{N} \times 6.25)$, fat and ash content were determined as described by AOAC (2002). Quality indices; total volatile basic nitrogen (TVB-N), Thiobarbituic acid (TBA) and $\mathrm{pH}$ value were determined as described by Pearson (1991). Trimethylamine nitrogen (TMA-N) was determined according to AOAC (2002). Total plate count (TPC) as follows: $10 \mathrm{~g}$ of sample were taken aseptically from different places of fish flesh and were homogenized with $90 \mathrm{ml}$ of sterilized buffer peptone water ( $1 \mathrm{~g}$ peptone in one liter distilled water). $1 \mathrm{ml}$ of appropriate dilutions was poured on the plate count agar (PCA, Oxide) as described by (FAO, 1979). The plates were incubated at $37^{\circ} \mathrm{C}$ for $48 \mathrm{~h}$ and the results obtained were expressed as $\log _{10} \mathrm{cfu} / \mathrm{g}$ sample. 


\section{RESULTS AND DISCUSSION}

\section{Sensory evaluation of cooked fish fillets}

Results of sensory tests (appearance, odor, texture, taste and overall acceptability) of different cooked fish fillets are shown in Figs. (1- a, b, c, \& d).
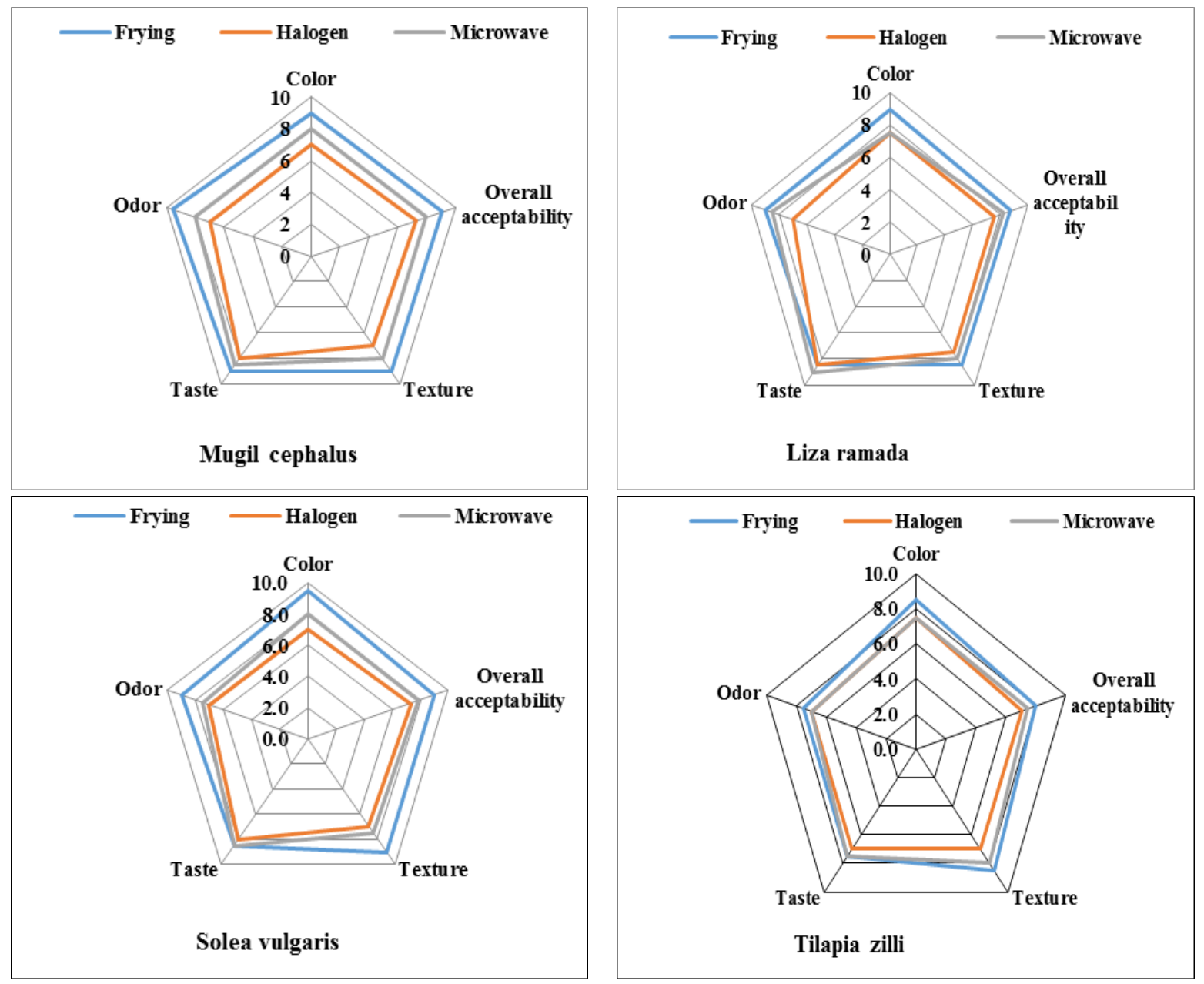

Fig. (1). Sensory tests of cooked fish fillets: (a) M. cephalus, (b) L. ramada, (c) $S$. vulgaris, (d) T. zilli.

There is no doubt that cooking methods improved acceptability of fish products, therefore all fried fish products had been given high scores and followed by microwave and halogen cooked products. Also, fried tilapia, T. zilli product was more preferred than other ones. On the other side, all cooked sole fish, $S$. vulgaris products had been given low scores of appearance. Besides, the scores of odor, texture, taste and overall acceptability of different cooked fish products were taken the same trends with exception fried grey mullet, $M$. cephalus product has the best odor and taste than others. Besides, all fried fish products were the best in texture and acceptability compared with microwave and halogen- cooked products. 


\section{Proximate composition of raw and cooked fish fillets}

Proximate composition of fish is often necessary to meet the requirements of food regulations and commercial specifications (Waterman, 2000). The proximate composition of raw and different cooked fish fillets are presented in Table (1). Moisture content ranged from $73.90 \%$ (M. cephalus) to $78.65 \%$ (S. vulgaris) in raw fish fillets. Concerning the effect of cooking techniques on moisture content, moisture reduced to59.26- $61.60 \%, 61.50-65.30 \%$ and $65.88-70.45 \%$ of fried, microwave and halogen cooked fillets, respectively. Reduction in moisture in cooked products is due to partially loss of water by evaporation, dripping of moisture and some components during cooking. Initial crude protein (ww) of raw fish fillets ranged from 18.36 to $19.51 \%$, increased apparently to $27.82-29.06 \%, 25.45-28.10 \%$ and $23.53-26.21 \%$ in fried, microwave and halogen cooked fish fillets, respectively.

Table (1). Proximate composition of raw and different cooked fish fillets.

\begin{tabular}{|c|c|c|c|c|c|}
\hline Item & Moisture (\%) & $\begin{array}{c}\text { Crude Protein } \\
(\%)\end{array}$ & Fat $(\%)$ & $\operatorname{Ash}(\%)$ & $\begin{array}{l}\text { Energy } \\
\text { (K Cal.) }\end{array}$ \\
\hline \multicolumn{6}{|c|}{ Mugil cephalus } \\
\hline Raw & $73.90 \pm 0.44$ & $19.51 \pm 1.38$ & $5.12 \pm 0.16$ & $1.47 \pm 0.36$ & 124.12 \\
\hline Frying & $59.26 \pm 2.12$ & $29.06 \pm 0.95$ & $9.51 \pm 0.22$ & $2.17 \pm 0.15$ & 201.83 \\
\hline Microwave & $61.50 \pm 1.18$ & $28.10 \pm 2.37$ & $8.50 \pm 0.89$ & $1.90 \pm 0.28$ & 188.90 \\
\hline Halogen & $66.18 \pm 0.35$ & $26.20 \pm 0.86$ & $5.62 \pm 0.72$ & $2.00 \pm 0.27$ & 155.38 \\
\hline \multicolumn{6}{|c|}{ Liza ramada } \\
\hline Raw & $75.70 \pm 2.29$ & $18.71 \pm 1.09$ & $4.01 \pm 0.35$ & $1.58 \pm 0.54$ & 110.93 \\
\hline Frying & $61.60 \pm 1.54$ & $28.20 \pm 1.07$ & $7.30 \pm 0.72$ & $2.90 \pm 0.33$ & 178.50 \\
\hline Microwave & $65.30 \pm 1.95$ & $26.95 \pm 1.37$ & $5.80 \pm 0.10$ & $1.95 \pm 0.37$ & 160.00 \\
\hline Halogen & $70.45 \pm 2.06$ & $23.53 \pm 0.57$ & $4.47 \pm 0.41$ & $1.50 \pm 0.005$ & 134.35 \\
\hline \multicolumn{6}{|c|}{ Solea vulgaris } \\
\hline Raw & $77.60 \pm 2.04$ & $18.36 \pm 0.87$ & $2.22 \pm 0.81$ & $1.80 \pm 0.36$ & 84.66 \\
\hline Frying & $60.18 \pm 0.50$ & $27.82 \pm 0.92$ & $8.90 \pm 0.56$ & $3.10 \pm 0.27$ & 191.38 \\
\hline Microwave & $63.22 \pm 2.03$ & $25.45 \pm 1.05$ & $7.50 \pm 0.64$ & $3.83 \pm 0.25$ & 169.30 \\
\hline Halogen & $65.88 \pm 1.01$ & $25.08 \pm 1.22$ & $5.30 \pm 0.68$ & $3.74 \pm 0.10$ & 148.02 \\
\hline \multicolumn{6}{|c|}{ Tilapia zilli } \\
\hline Raw & $78.65 \pm 0.73$ & $19.01 \pm 1.17$ & $1.11 \pm 0.73$ & $1.20 \pm 0.66$ & 86.03 \\
\hline Frying & $61.46 \pm 1.11$ & $28.33 \pm 2.43$ & $7.20 \pm 0.83$ & $3.01 \pm 0.93$ & 178.12 \\
\hline Microwave & $64.70 \pm 3.41$ & $27.00 \pm 1.71$ & $4.79 \pm 0.32$ & $3.49 \pm 0.79$ & 151.11 \\
\hline Halogen & $68.38 \pm 2.12$ & $26.21 \pm 1.59$ & $2.96 \pm 0.61$ & $2.45 \pm 0.29$ & 131.48 \\
\hline
\end{tabular}

Values are shown as mean \pm standard deviation of triplicates.

This increment in protein is due to denaturation of protein as resultant of water loss by cooking temperature. On the other side, lipid content (ww) of raw fish fillets 
ranged from $1.11 \%$ (T. zilli) to $5.12 \%$ (S. vulgaris), increased apparently to $7.20-9.51 \%$, $4.79-8.50 \%$ and $2.96-5.62 \%$ in fried, microwave and halogen cooked fish fillets, respectively. This increment is due to denaturation of protein as resultant of water loss by cooking temperature. An increase in fat content of fried fillets is due to water loss throughout cooking processes and oil absorption of deep-oil frying. Besides, ash content (ww) of raw fish fillets ranged from $1.20 \%$ (T. zilli) to $1.80 \%$ (S. vulgaris), increased apparently to $2.17-3.10 \%, 1.90-3.83 \%$ and $1.50-3.74 \%$ in fried, microwave and halogen cooked fish fillets, respectively. An increase is due to water loss as affected by cooking methods. In general, our results are in agreement with those findings by several studies (García-Arias et al., 2003; Gokoglu et al., 2004; Bochi et al., 2008; Weber et al., 2008; Hakimeh, et al., 2010; Mnari-Bhouri et al., 2010; Kocatepe et al., 2011; Oduro et al., 2011; Uran \& Gokoglu, 2011; Koubaa, et al., 2012; Marimuthu et al., 2012 and Talab, 2014). They showed that the different cooking methods led to decrease in moisture content and increase in total protein, lipid and ash content (i.e. rise in dry matter) in fish fillets compared with raw samples. However, other study (Oğuzhan \& Angis, 2013) found that protein, fat and moisture contents of hot smoked, cold smoked, grilled and fried rainbow trout fillets were found to be highly significant $(\mathrm{P}<0.01)$ but ash content was found to be non-significant $(\mathrm{P}>0.05)$ for all processing methods. Bainy $\boldsymbol{e}$ a al. (2015) reported that cooking method did not affect the chemical composition, but influenced the texture and color parameters of the tilapia fish burgers.

\section{Quality attributes}

The $\mathrm{pH}$ value of fish muscle is usually a good index for quality assessment. It is important determining of fish quality as texture of fish (Rathod \& Pagarkar, 2013). Table (2) showed some quality attributes of raw and different cooked fish fillets. The $\mathrm{pH}$ values of raw fish fillets ranged 6.48-6.60, slightly changed to reach 6.33-6.55, 6.60-6.82 and 6.55-6.65 in fried, microwave and halogen cooked fish fillets, respectively. A negligible change in $\mathrm{pH}$ values cooked filets is due to breakage of hydrogen bond and electrostatic interactions as reported by Dhanapal et al. (2012). Total Volatile Basic Nitrogen (TVB-N) is mainly composed of ammonia, trimethylamine (TMA) and thiobarbituric acid (TBA) are widely used as an indicator of meat deterioration (Fan $\boldsymbol{e} t$ al., 2008). The TVB-N content (ww) of raw fish fillets ranged from 14.0 (S. vulgaris) to 17.5 (T. zilli) $\mathrm{mg} / 100 \mathrm{~g}$ sample. After cooking processes, all values were slightly decreased to $13.20-17.12,13.5-17.45$ and $13.40-17.30 \mathrm{mg} / 100 \mathrm{~g}$ sample in fried, microwave and halogen cooked fish fillets, respectively. This slight reduction occurred in TVB-N content may be volatilization of some volatile bases as affected by cooking conditions. The same trend was observed in case of TMA content. Trimethylamine (TMA) is produced by the decomposition of trimethylamine $\mathrm{N}$-oxide caused by bacterial spoilage and enzymatic activity. Values of TMA were ranged from 0.95 (L. ramada) to 1.95 (T. zilli) $\mathrm{mg} / 100 \mathrm{~g}$ sample, it reduced slightly to $0.80-1.70,0.93-1.90$ and $0.85-1.80$ $\mathrm{mg} / 100 \mathrm{~g}$ sample in fried, microwave and halogen fillets, respectively. 
Table (2). Physiochemical and microbial properties of raw and different cooked fish fillets

\begin{tabular}{llllll}
\hline item & pH value & $\begin{array}{l}\text { TVB-N } \\
(\mathrm{mg} / 100 \mathrm{~g})\end{array}$ & $\begin{array}{l}\text { TMA-N } \\
(\mathrm{mg} / 100 \mathrm{~g})\end{array}$ & $\begin{array}{l}\text { TBA } \\
(\mathrm{mg} \mathrm{MA} / \mathrm{kg})\end{array}$ & $\begin{array}{l}\text { TPC } \\
\left(\mathrm{Log}_{10} \mathrm{cfu} / \mathrm{g}\right)\end{array}$ \\
\hline Raw & $6.48 \pm 0.040$ & $16.18 \pm 0.385$ & $1.01 \pm 0.046$ & $0.75 \pm 0.004$ & $2.85 \pm 0.029$ \\
Frying & $6.42 \pm 0.041$ & $15.20 \pm 0.866$ & $0.80 \pm 0.040$ & $0.67 \pm 0.012$ & $2.45 \pm 0.032$ \\
Microwave & $6.82 \pm 0.020$ & $16.01 \pm 0.357$ & $0.93 \pm 0.020$ & $0.55 \pm 0.029$ & $2.66 \pm 0.033$ \\
Halogen & $6.64 \pm 0.036$ & $15.50 \pm 0.903$ & $0.85 \pm 0.021$ & $0.49 \pm 0.021$ & $2.75 \pm 0.036$ \\
& & \multicolumn{5}{c}{ Liza ramada } & & \\
Raw & $6.60 \pm 0.020$ & $16.55 \pm 0.396$ & $0.95 \pm 0.023$ & $0.80 \pm 0.032$ & $2.78 \pm 0.020$ \\
Frying & $6.55 \pm 0.077$ & $15.90 \pm 0.892$ & $0.90 \pm 0.008$ & $0.76 \pm 0.012$ & $2.50 \pm 0.023$ \\
Microwave & $6.72 \pm 0.020$ & $16.01 \pm 0.133$ & $0.94 \pm 0.008$ & $0.75 \pm 0.023$ & $2.62 \pm 0.020$ \\
Halogen & $6.65 \pm 0.012$ & $16.50 \pm 0.860$ & $0.93 \pm 0.020$ & $0.70 \pm 0.047$ & $2.65 \pm 0.032$ \\
& & \multicolumn{5}{c}{ Solea vulgaris } & & \\
Raw & $6.48 \pm 0.043$ & $14.00 \pm 0.008$ & $1.30 \pm 0.047$ & $0.90 \pm 0.016$ & $2.92 \pm 0.064$ \\
Frying & $6.33 \pm 0.020$ & $13.20 \pm 0.793$ & $1.02 \pm 0.008$ & $0.85 \pm 0.016$ & $2.65 \pm 0.032$ \\
Microwave & $6.66 \pm 0.033$ & $13.50 \pm 0.554$ & $1.25 \pm 0.026$ & $0.80 \pm 0.020$ & $2.73 \pm 0.020$ \\
Halogen & $6.60 \pm 0.009$ & $13.40 \pm 0.453$ & $1.10 \pm 0.068$ & $0.45 \pm 0.040$ & $2.80 \pm 0.040$ \\
& & \multicolumn{5}{c}{ Tilapia zilli } & & \\
Raw & $6.52 \pm 0.020$ & $17.50 \pm 0.784$ & $1.95 \pm 0.023$ & $0.70 \pm 0.023$ & $2.80 \pm 0.047$ \\
Frying & $6.49 \pm 0.041$ & $17.12 \pm 0.186$ & $1.70 \pm 0.026$ & $0.65 \pm 0.032$ & $2.50 \pm 0.081$ \\
Microwave & $6.60 \pm 0.081$ & $17.45 \pm 0.312$ & $1.90 \pm 0.008$ & $0.68 \pm 0.020$ & $2.70 \pm 0.040$ \\
Halogen & $6.55 \pm 0.040$ & $17.30 \pm 0.604$ & $1.80 \pm 0.077$ & $0.50 \pm 0.020$ & $2.75 \pm 0.020$ \\
\hline
\end{tabular}

Values are shown as mean \pm standard deviation of triplicates.

Concerning thiobarbituric acid (TBA), TBA values were ranged from 0.70 ( $T$. zilli) -0.90 (S. vulgaris) mg MA/kg sample, decreased slightly to $0.65-0.85,0.55-0.80$ and 0.45-0.70 mg MA/kg sample, in fried, microwave and halogen-cooked fish fillets, respectively. This decrement in TBA values of cooked fillets may be attributed to the interaction of decomposition products of protein with malonaldehyde to give tertiary products. Similar findings are reported by many authors (Tokur et al., 2004; Talab, 2014; Bastías, et al., 2017 and Hernández-Sánchez et al., 2020). Total plate count (TPC) of raw fish fillets ranged from 2.78 (L. ramada) to 2.92 (S. vulgaris) $\log _{10} \mathrm{cfu} / \mathrm{g}$ sample, reduced markedly to $2.45-2.65,2.65-2.73$ and $2.65-2.80 \log _{10} \mathrm{cfu} / \mathrm{g}$ sample of fried, microwave and halogen - cooked fish fillets, respectively. This reduction occurred in cooked fillets is due to effect of cooking conditions in particular vegetative cells. 


\section{CONCLUSION}

All cooking techniques; frying, microwave and halogen techniques caused significant changes in sensory analysis, chemical composition and quality indices of investigated fishes. Besides, all fried fillets fish products were the best in texture and total acceptability compared with microwave and halogen- cooked products.

\section{REFERENCES}

AOAC, (2002). Association of Official Analytical Methods. Official Methods of Analysis. $16^{\text {th }}$ ed. Arlington, Virginia. USA.

Bainy, E.M.; Bertan, L.C.; Corazza, M.L. and Lenzi, M.K. (2015). Effect of grilling and baking on physicochemical and textural properties of tilapia (Oreochromis niloticus) fish burger. J. Food Sci. Technol., 52(8):5111-5119.

Bastıas J.M.; Balladares P.; Acuña S.; Quevedo R. and Muñoz O. (2017). Determining the effect of different cooking methods on the nutritional composition of salmon (Salmo salar) and chilean jack mackerel (Trachurus murphyi) fillets. PLOS ONE 12(7): e0180993. https://doi.org/10.1371/ journal.pone.0180993.

Bochi, V.C.; Weber, J.; Ribeiro, C.P.; Victório, A.M. and Emanuelli, T. (2008). Fish burgers with silver catfish (Rhamdia quelen) filleting residue. Bioresour Technol., 99: 8844-8849.

Bognar, A. (1998). Comparative study of frying to other cooking techniques influence on the nutritive value. Grasas Aceites., 49: 3-4.

Dhanapal, G.; Vidya, S.R.; Binay, B.N.; Venkateswarlu, G.; Devivaraprasad, R.A. and Basu, S. (2012). Effect of cooking on physical, biochemical, bacteriological characteristics and fatty acid profile of Tilapia (Oreochromis mossambicus) fish steaks. Arch. Appl. Sci. Res., 4 (2): 1142-1149.

Fan, W.; Sun, J.; Chen, Y.; Qiu, J.; Zhang, Y. and Chi, Y. (2008). Effects of chitosan coating on quality and shelf life of silver carp during frozen storage. Food Chem., 115(1): 66-70.

FAO, (1979). Manual of Food Quality Control. 4. Microbiological Analysis Food and Agriculture Organization of the United Nation, 1414 PP.C 9-12.

García-Arias, M.T.; Alvarez-Pontes, E.; García-Linares, M.C.; García-Fernández, M.C. and Sánchez-Muniz, F.J. (2003). Cooking-freezing-reheating (CFR) of sardine (Sardina pilchardus) fillets. Effect of different cooking and reheating procedures on the proximate and fatty acid compositions. Food Chem., 83: 349-356.

Gokoglu, N.; Yerlikaya, P. and Cengiz, E. (2004). Effects of cooking methods on the proximate composition and mineral contents of rainbow trout (Oncorhynchus mykiss). Food Chem., 84: 19-22. 
Hakimeh, J.A.; Akram, A.A.; Bahareh, S. and Alireza, S.M. (2010). Effects of cooking methods on physicochemical and nutritional properties of Persian sturgeon (Acipenser persicus) fillets. Int. Aquat. Res., 2: 15-23.

Hernández-Sánchez F.; Aguilera-Morales, M.; Lorenzo, J.L.; Navarro-Moreno, L. and Yie-Hua, T. (2020). Effect of different cooking methods on the nutritional composition of Tilapia (Oreochromis sp.). Journal of Applied Science \& Process Engineering, 7(1): 489-499.

Hugas, M.; Garriga, M. and Monfort, J.M. (2002). New mild technologies in meat processing: high pressure as a model technology. Meat Sci., 62: 359-371.

Karamer, A. and Twigg, B.A. (1970). Quality Control for the Food Industry. $3^{\text {rd }}$ Ed. AVI Publishing Co., Wesport Conn. London, England.

Kocatepe, D.; Turan, H.; Taşkaya, G.; Kaya, Y.; Erden, R. and Erdoğdu, F. (2011). Effects of cooking methods on the proximate composition of black sea anchovy (Engraulis encrasicolus, Linnaeus 1758). GIDA, 36(2): 71-75.

Koubaa A.; Mihoubi, N. B.; Abdelmouleh, A. and Bouain, A., (2012). Comparison of the effects of four cooking methods on fatty acid profiles and nutritional composition of Red Mullet (Mullus barbatus) muscle. Food Sci. Biotechnol., 21(5): 1243-1250.

Larsen, R.; Stormo, S.K.; Dragnes, B.T. and Elvevoll, E.O., (2007). Losses of taurine, creatine, glycine and alanine from cod (Gadus Morhua L.) fillet during processing. J. Food Compos. Anal., 20: 396-402.

Marimuthu, K.; Thilaga, M.; Kathiresan, S.; Xavier, R. and Mas, R. H., (2012). Effect of different cooking methods on proximate and mineral composition of striped snakehead fish (Channa striatus, Bloch). J. Food Sci. Technol., 49(3): 373-377.

Mnari-Bhouri, A.; Harzallah, H.J.; Dhibi, M.; Bouhlel, I.; Hammami, M. and Chaouch, A. (2010). Nutritional fatty acid quality of raw and cooked farmed and wild sea bream (Sparus aurata). J. Agric. Food Chem., 58: 507-512.

Oduro, F.A.; Choi, N.D. and Ryu, H.S. (2011). Effects of cooking conditions on the protein quality of chub mackerel, Scomber japonicas. Fish Aquat. Sci., 14(4): 257265.

Oğuzhan, P. and Angis, S. (2013). Effects of processing methods on the sensory, mineral matter and proximate composition of rainbow trout (Oncorhyncus mykiss) fillets. Afric. J. of Food Sci. and Tech., 4(4): 71-75.

Pearson, D. (1991). The Chemical Analysis of Food. Churchill, NewYork, London, 374410.

Rathod, N. and Pagarkar, A. (2013). Biochemical and sensory quality changes of fish cutlets, made from pangasius fish (Pangasianodon hypophthalmus), during storage in refrigerated display unit at -15 to $-18^{\circ} \mathrm{C}$. Int. J. Food Agric. Vet. Sci., 3(1): 1-8.

Steel, R.G. and Torri, J.H. (1980). Principles procedure of statistics'. Mc Graw- Hill, New York, USA, pp. 120 
Talab, A.S. (2014). Effect of cooking methods and freezing storage on the quality characteristics of fish cutlets. Advance J. of Food Sci. and Tech., 6(4): 468-479.

Tokur, B.; Polat, A.; Beklevik, G. and Ozkutuk, S. (2004). Changes in the quality of fish burger produced from Tilapia (Oreochromis niloticus) during frozen storage ($\left.18^{\circ} \mathrm{C}\right)$. Eur. Food Res. Technol., 218: 420-423.

Uran, H. and Gokoglu, N. (2011). Effects of cooking methods and temperatures on nutritional and quality characteristics of anchovy (Engraulis encrasicholus). Journal of Food Science and Technology, 51(4):722-728. DOI 10.1007/s 13197-011- 0551-5.

Waterman, J.J. (2000). Composition and Quality of Fish. Torry Research Statation. Edinburgh.

Weber, J.; Bochi, V.C.; Ribeiro, C.P.; Victorio, A.M. and Emanuelli, T. (2008). Effect of different cooking methods on the oxidation, proximate and fatty acid composition of silver catfish (Rhamdia quelen) fillets. Food Chem., 106: 140-146. 